\title{
"They Always Have My Back: A Strengths-Based Approach to Understanding the Value(s) of Pasifika Brotherhoods in Education in Aotearoa New Zealand
}

\author{
Martyn Reynolds \\ Victoria University of Wellington \\ New Zealand
}

\begin{abstract}
Set in Aotearoa New Zealand, this examination of "Pasifika" education as an inter-cultural event discusses what students from the Pacific diaspora say about educational success. Against a backdrop of literature that pays attention to teacher-student relationships, achievement targets, and peer relationships, the article uses Pacific concepts to theorise the dynamics between individuals, "brotherhood" groups, and success. It suggests that teachers and institutions might respond better in intercultural situations by "looking backwards to walk forwards."
\end{abstract}

KEYWORDS: brotherhood, equity, Pasifika education, relationality, Aotearoa New Zealand

\author{
Pasifika Education \\ Three Strands of Literature \\ The Study \\ Implications \\ Concluding Comments \\ Acknowledgements \\ Note \\ References \\ Author Contact
}

In Aotearoa New Zealand ${ }^{1}$, paths to the enhancement of Pasifika education, the education of students with links to Pacific Islands, have been subject to calls to improve relationships and target learners. Within the literature, some consideration has been paid to Pasifika peer-relationships, particularly "brotherhoods" among boys. This article examines what students in a single-sex boys' high school say about their brotherhood. Pasifika voice, theorised through va (relationality), provides an account of the importance of success as being accepted and of ways that this can intersect with success as resilience.

The argument acknowledges Pasifika relationality as a strength and suggests the importance of shaping contexts to minimise conflicts between different forms of success. This approach supports a holistic reading of Pasifika 
education in which reframed institutional practice can clear the path for Pasifika students to pursue their own success as Pasifika. By implication, the paper suggests the value of understanding diverse groups in their own terms, seeking to re-view educational encounters in multicultural situations. While this is not new, an additional pathway to understanding and supporting diverse student populations comes from encompassing group-based ethics where group identity is powerful in students' understandings of the world.

\section{Pasifika Education}

Aotearoa New Zealand is a bicultural nation in which the Treaty of Waitangi, signed between various Māori chiefs and representatives of the British Crown in 1840, has shaped the relationship between indigenous Māori and other groups (Orange, 2012). Among non-Māori who reside in Aotearoa New Zealand are people who have migrated from the many island nations of the Pacific.

Historically, members of the Pacific diaspora living in Aotearoa New Zealand were called Polynesian people (Tanielu \& Johnson, 2013). However, various government bodies refer, for contextual reasons, to such migrant groups by other terms. These include Pacific peoples (Statistics New Zealand, 2014) and Pacific heritage/Pacific (Education Review Office, n.d.). The term P.I. (Pacific Islander) also has currency (Anae, 2005/2015), reflecting an ethnogenesis (Spoonley, 1988) as members of various Pacific Island groups in Aotearoa New Zealand marry, have children, or relate in other ways. In recent years, the Ministry of Education (MoE) has popularised the term Pasifika (Tanielu \& Johnson, 2013) within education. The MoE uses Pasifika to refer to "those peoples who have migrated from Pacific nations and territories. It also refers to the New Zealandbased (and born) population, who identify as Pasifika, via ancestry or descent" (Airini, Mila-Schaaf, Coxon, Mara, \& Sanga, 2010, p. 49).

Pasifika as a grouping in education is contested. An umbrella term such as Pasifika has relational, political, and historical resonance. This is because the "nature of Pasifika groups residing in New Zealand tends to reflect historical and colonial relationships New Zealand has had in the Pacific region" (Airini et al., 2010, p. 49), a consequence of colonialism and diaspora. Pasifika education is itself intercultural; Pasifika students are taught by a mostly Palagi (European origin) teaching force in a British-origin system.

As a "term of convenience" (Airini et al., 2010, p. 49), one may ask whose convenience Pasifika is serving in education. The Pasifika umbrella (Samu, 2006) carries the danger of aggregating diverse populations, and there have been calls for "ethnic-specific approaches, information and determination" in Pasifika educational research (Airini et al., 2010, p. 49). But disaggregation is not a silver bullet. As Airini et al. note, "Even within ethnic-specific groups, there is a danger of glossing over intra-ethnic variations" (p. 49). While official usage may cement the relevance of Pasifika in policy (Ministry of Education, 2013), context dictates 
the validity and usefulness of Pasifika in practice. For instance, at home students might see themselves as Tongan, Samoan, etc., but at school they may identify to some extent as Pasifika, embracing commonalities with their Pasifika friends. Such thinking is not exclusionary, but fluid and contextual. Similarly, the notion of Pasifika may be more relevant in some schools than others depending on the origins, numbers, attitudes, and experiences of those attending.

The use of Pasifika as a data category exposes the relatively low achievement of Pasifika students in national assessment such as the National Certificate of Educational Achievement (NCEA) (e.g., New Zealand Qualifications Authority, 2013, 2014, 2015; Turner, Irving, Li, \& Yuan, 2010). Disparity has stimulated policy initiatives (e.g., Ministry of Education, 2013), statistical research (e.g., Wilson, Madjar, \& McNaughton, 2016), and school-based programmes (Reynolds, 2017b). The results of summative assessments such as NCEA are founded on experiences of education as a process. This paper examines aspects of students' day-to-day experiences of Pasifika education through Pasifika voice, the words of a group of boys with links to several Pacific Island nations including Tonga, Samoa, Fiji, Niue, and Tokelau.

\section{Three Strands of Literature}

For research that seeks to expose the dynamics of in-school processes in Pasifika education, three strands of literature are most relevant. These concern teacher-student relationships, educational targeting initiatives, and peer group interaction.

\section{Teacher-Student Relationships}

Education is generally experienced by Pasifika students through relationships with Palagi teachers. Shifting theorisation has characterised this strand. Deficit theorising was used early on to explain a relative lack of Pasifika achievement (Alton-Lee, 2003; Gorinski \& Fraser, 2006; Nakhid, 2003). Such literature conceptualised in-school processes, relationships, and outcomes as dominated by out-of-school factors, removing agency from teachers and schools and pathologizing Pasifika students for being Pasifika.

More recently, student-teacher relationships in Pasifika education have been subject to strengths-based theorisation. This values what students bring to school, specifically language, culture, and identity. In this literature, attention focuses on in-school relational activity-there is no external community to blame. One line of inquiry, based on Pasifika voice, has asked how teacher-student relationships can be reformed to make being Pasifika a strength. Taxonomic accounts of characteristics of successful teachers exist (e.g., Hawk \& Hill, 2000; Siope, 2011). These describe what some teachers bring to relational activity 
through meeting the expectations of Pasifika students. Teachers favoured by Pasifika students are described as special or going the "extra mile" (Evans, 2011, p. 72). Extraordinariness may be significant for rarity value, saying much about common practice, which is founded on implicit, historically defined, and professionally propagated notions held by teachers of their role (Spiller, 2013).

A Pacific account of education suggests that cultural expectation can sit behind Pasifika student preferences (Helu-Thaman, 1988). Here, relationallyfocused teachers are significant for meeting culturally-founded obligations. HeluThaman (2010) describes the role of a teacher in Tonga to include "nurturing positive relationships and social responsibility" (p. 356). This role description includes being a moral agent rather than simply delivering curriculum. If Pasifika students bring similar expectations of their teachers to school, a cultural rather than a personal explanation of Pasifika student relational preferences in education may be useful in research.

\section{Targeting}

A second strand in the literature of Pasifika education concerns targeting. This is largely grey literature, the output of government agencies (e.g., Education Review Office, 2012; Ministry of Education, 2015). In recent years, Pasifika students have been described as "priority learners" (e.g., Education Review Office, n.d.) and as "target students" (e.g., Office of the Auditor-General, 2012). This can lead to additional monitoring and support for students, but can also result in attempts by schools to meet targets set for themselves as institutions by "subsidising" the achievement of certain students with less-valued qualifications (Boereboom, 2016, paragraph 5). Finally, Pasifika students have been characterised as a group "poorly served" by the education system (e.g., Treasury, 2012). This shift is welcome if critical focus is placed on relationships between policy makers, administrators, schools, and Pasifika students and allied to constructive change.

However understood, targeting is a feature of Pasifika education. The kinds of targets set for the education system and consequently by proxy for schools can be seen in the Pasifika Education Plan (PEP). The vision of the PEP is "five out of five Pasifika learners participating, engaging and achieving in education, secure in their identities, languages and cultures and contributing fully to Aotearoa New Zealand's social, cultural and economic wellbeing" (Ministry of Education, 2013, p. 3). Targeting, however, is unevenly spread between these key areas. Overwhelming attention is paid to achievement. Achievement targets have been established, the most visible of which refers to the rate of Pasifika attainment of NCEA Level 2 (generally undertaken in Year 12 of secondary education by students aged about 16), even though this is not the key level for progress to tertiary education. 
By contrast to the PEP, the Education Review Office (ERO), which is responsible for monitoring the quality of provision in schools, pays wider attention (Education Review Office, 2012). ERO reports on how schools exhibit compliance in key areas identified by ERO as significant for Pasifika educational advancement as well as on achievement data. ERO reporting is, however, less visible than MoE celebrations of achievement rates (e.g., Redmond, 2017). Some have argued that the equity of experiencing education as a culturally affirming process leading to achievement is silenced by concentration on equality measured through an overwhelming focus on achievement itself (Milne \& Students of Kia Aroha College, 2015).

\section{Pasifika Brotherhoods}

A third strand of literature concerns peer relations in Pasifika education, specifically among boys in so-called "brotherhoods," often explored in the context of "Poly Club" or Pasifika cultural performance group. A Poly Club is a space where students learn, teach, practice, and perform items of dance and song that come from, or are in the language of, one or more Pacific Island groups. Although this literature is thin, studies of brotherhoods gain significance when the relative NCEA achievement rates of Pasifika boys and Pasifika girls are considered (New Zealand Qualifications Authority, 2015).

Fairbairn-Dunlop (2010a) describes gendered, culturally framed forms of success embedded in a brotherhood of Samoan-origin peers. She reports that peer-defined forms of success and success as academic achievement intersect in complex ways, speculating that peer-supported, gendered cultural constructions of success may inhibit Samoan males from academic achievement. That is, one form of success may eclipse another. Fairbairn-Dunlop (2010b) reports a positive correlation between academic success and involvement in a Poly Club by comparing the academic outcomes of Pasifika students involved in performance and those uninvolved. In her work, however, despite a correlation between membership and relative achievement, club members were unable to explain why their level of commitment to the club did not spill over into similar levels of commitment to other aspects of the school such as academia.

Rimoni (2016) also describes the importance of school-based brotherhoods to Samoan boys in Aotearoa New Zealand. Her research suggests that brotherhoods are of special significance in single-sex school contexts and that, particularly in schools where the Pasifika cohort is a small minority, a Poly Club can be a meeting and connecting place where a brotherhood is focused. In her account, a brotherhood acts to support students, "has an immense influence on how they feel about the school environment" (p.124), can be a fundamental reason for being at school, and can condition, through loyalty, the way experiences of school are understood. In addition, a brotherhood is reciprocal. Students in Rimoni's study could "identify the code of responsibility that went with being part of the brotherhood" (p.126). The idea of boys being of great influence on each 
other in a Pasifika context is present elsewhere. Samu (2015) found that in Pasifika education, friends are "motivating factors, supporters, brothers-in some ways a de facto family" (p. 25). According to the boys who were his respondents, this kind of friendship is exclusively among males.

Pasifika peer relationships have also been depicted as important in mentoring/tutoring and in collaborative learning. McMillan (2012) argues that Pasifika (and Mãori) boys can be socialised into the expectations of the classroom environment by discussing male identity within a club-type forum. This suggests that group-based relational language developed in one cultural space can be useful in unpacking another relational language for another cultural space. In the tertiary sector, Latu and Young (2004) describe the value of collaborative learning for students with Pacific Island origins, and Latu (2004) reports the success of Pasifika peer-supported learning in mathematics. Alkema (2014) reviews literature from the tertiary sector that values strong peer relationships as an element in academic success for Pasifika students.

It is possible to integrate the limited strand of peer-based literature with that regarding student-teacher relationships by speculating that the relationality that Pasifika students seek with peers is in some ways like their preferred relationships with teachers. Both teacher- and peer-based literature foreground commitment, reciprocity, and emotionality. However, the means of reproducing relationality from the peer/cultural performance space in the peer/teacher/academic space are less clear. Schools may hope that there will be a transfer of enthusiasm and commitment from Poly Clubs to other areas of institutional life, but such a hope assumes that schools are understood by Pasifika students as a single space rather than as a collection of spaces. There is an absence of research which directly attempts to examine the potential for modelling teacher-student relationality on peer relationships in Pasifika education even though the research cited above may indirectly suggest this as a way forwards.

\section{The Study}

This study seeks to address the question "What is Pasifika success as Pasifika?" in the context of education. This is an important question to ask, particularly for a teacher interacting with Pasifika students daily in class, because the answer has the potential to impact on practice. Ideas of success are clearly expressed in Pasifika education through the setting of targets as discussed above (Ministry of Education, 2013, 2015). However, success can also be understood as the achievement of goals underpinned by values. In this view, Pasifika success is related to Pasifika culture(s) and, while likely to include achievement, may embrace wider goals for Pasifika education (Alkema, 2014; Toumu'a, 2014).

Ethics in Pasifika educational research are an edgewalk (Tupuola, 2004). That is, ethics must satisfy both the academy and the Pasifika community/ies. To achieve this, a researcher must develop fluency in negotiating between the various 
understandings and expectations involved. Through measures such as privacy, the management of conflicts of interest, and others, this study adhered to Victoria University of Wellington ethics protocols by providing evidence that no harm would be done. However, the study additionally sought to satisfy the ethical expectations of the Pasifika research community as well as of participants from the Pasifika community. Following the understandings of Airini et al. (2010), the study sought to do good, to be "making a difference to Pasifika education" (Visser, Unasa, Kennedy, \& Airini, 2007), and to achieve this through a focus on the ethical configuration of relationships in the research process.

As a Palagi teacher-researcher of British origin, I know that embracing Pasifika research ethics means paying attention to a continual process of negotiation around shared ownership, reciprocal responsibilities, and mutual benefit. In practice, matters such as design, implementation, the interpretation of data, and similar issues are passed back and forth between the researcher and various participants and advisors to honour ethical commitments. For example, the main consultation session with parents was timed, convened, and chaired by a community member. The interpretation of the data gathered there was assisted by community members and then shared with teachers. When teachers had enacted their learning from the data, they developed accounts of their actions. I then passed these accounts on their behalf to parents. In this way, the research became something achieved together, founded on relationships that were configured through a shared commitment to Pasifika students.

This study was a bounded case-study. It sought the understandings of Pasifika students and their parents at a particular place and time in an educational journey. The place was a single institution. Airini et al. (2010) discuss the contextual fluidity of identity under the Pasifika umbrella and the value of context in research as an ethical consideration, suggesting that context is the key to understanding the interactions of multiple identities in Pasifika education. Identity is affected by many factors that can include specific educational experiences. In formal education, these are generally centred on a school. Pasifika students can have their own contextual reasons for selecting a school such as family history, location, institutional reputation, or ethnic and social factors (Reynolds, 2017a). As indicated by Rimoni (2016), the single-sex/coeducational profile of a school also can be important. The value of a single institution case study such as this is the potential to reveal salient aspects of context as they affect ideas about Pasifika success as Pasifika.

The study was also bounded by time. The focus was on students' initial year in secondary education. The importance of better understanding Pasifika students' experiences at times of educational transition has been widely acknowledged (Chu, Glasgow, Rimoni, Hodis, \& Meyer, 2013). Investigating students' ideas of success at transition can reveal what students expect and want when they enter a new school. If educationalists can learn from this, student-defined success and a sense of belonging in support of achievement can be fostered right from the start of a new phase of education. 
There can be a tension between scale and detail in research. A small-scale study such as this is limited in direct generalisability precisely because of its contextual nature. However, such a study can reveal what Sanga calls "the context behind the context-the spheres or domain of social relationships within communities" (as cited in Airini et al., 2010, p.11). Deeply contextual information is important to help us "know much better what we are trying to deal with" on a wider scale (p. 11). Small scale studies which offer a tight and intense contextual focus that appreciates the complexities of experience can indicate the kinds of questions to ask more widely and profile the kinds of dynamics which might be significant elsewhere.

The study embraced a strengths-based, dialogical, and relational methodology. A strengths-based methodology assumes that students' funds of knowledge (Moll, 2015) are of value. In this case, this includes knowledge of Pacific origin. In a strengths-based Pasifika methodology, Pacific-based ways of understanding the world such as relationality and dialogue (Airini et al., 2010; Crocombe, 1976) become the basis for investigation and are built into design. A dialogic methodology involves the construction of opportunities for people to hear from each other in research with the aim of improving mutual understanding (Nakhid, 2003). In this case, dialogue was fostered between researcher and participants, students and teachers, and parents and teachers. A Pasifika dialogic methodology seeks to create space for interaction in which all can contribute and learn.

Relationality, already discussed in the context of Pasifika research ethics, is particularly important in educational research where the researcher is also a teacher at the research site. Clarity in the configuration of relationships is important to acknowledge and, if possible, avoids conflicts of interest. Pasifika educational research values closeness and discounts claims of objectivity. Relationships always exist between people (Airini et al., 2010), and close relationships are likely to foster mutual understanding. In this study, pre-existing relationships and prior educational experiences of friends and family members encouraged students and parents to participate, as did the informal sponsoring of the research by members of the school's Pasifika community. The basis of the relationality involved was not only to learn but to do-to create a basis for improvements in Pasifika education and, where possible, to execute these. In such an enterprise, the selection of a research site in which the researcher has a stake is an advantage. Relationality in Pasifika educational research can be understood through the concept of va, discussed in the following section.

The study took place in the setting of a boys' high school in Aotearoa New Zealand. In Aotearoa New Zealand, the decile of a school reflects the socioeconomic profile of its environment (although not of all of its students). The school's decile, 10, suggests a comparatively wealthy setting (Ministry of Education, 2016). Pasifika students form about six percent of the school's student body. Sixteen beginning students, roughly half of those in their year group, participated in a series of interviews and group talanoa (relationally mediated interactions) (Fa'avae, Jones, \& Manu'atu, 2016; Farrelly \& Nabobo-Baba, 2014; 
Suaalii-Sauni \& Fulu-Aiolupotea, 2014). Over a period of seven months, twelve interviews were conducted with pairs (or sometimes threes) of students, each lasting about 40 minutes. In addition, a number of less formal discussions took place at students' behest. In addition, two talanoa of similar length were conducted with students. One of these was facilitated by a senior student acting as research assistant; I conducted the other. These two sessions produced similar results. One main parental talanoa occurred with over a dozen participants, supported by three smaller talanoa of pairs and individuals talking with me. Informal contacts and follow-ups occurred as a result of normal contact between a teacher and parents connected through a school. An iterative approach was adopted so that ideas from one source or time could be further investigated in another context.

The focus of most of these interactions was to garner male Pasifika student voice on a range of issues related to forms of success. Following the literature, the study paid particular attention to relationships in Pasifika education. However, unlike some previous voice-based studies, an alternative and explicit analytical framework to replace default Western understandings of ideal relationships was employed in the form of va, a cultural reference from the Pacific.

\section{$\mathrm{Va}$}

Va has been glossed in English as the space between (Anae, 2010a) and as relationality (Poltorak, 2007). Although it would be presumptive to consider va as a Pacific cross-cultural understanding (Tuagalu, 2008), discussions of va often take place in the context of Tongan (e.g., Helu-Thaman, 1988; Ka'ili, 2005) or Samoan (e.g., Tuagalu, 2008; Wendt, 1999) settings. Va has also been described elsewhere in the region (e.g., Hoem, 1993). It is hard to honour va in a short article, but developing an understanding of this concept has potential for both contextualizing Pasifika voice and disturbing European relational lenses in ways that re-view Pasifika education.

Wendt (1999), writing from a Samoan perspective, describes va as "the space between, the betweenness, not empty space, not space that separates but space that relates, that holds separate entities and things together in the Unitythat-Is-All, the space that is context, giving meaning to things" (p. 402). Similarly, Ka'ili (2005), writing from a Tongan position, says va "emphasises space in between. This is fundamentally different from the popular western notion of space as an expanse or an open area" (p. 89). Focusing on va can lead to "an examination of our interaction with others; a focus on our intentions and conscious actions that influences the nature of our relationships with others" (Mila-Schaaf, 2006, p. 11). Further discussion is found in Anae (2010b), Lilomaiava-Doktor (2009), and Reynolds (2016).

Hau'ofa's (1994) understanding of the islands of Oceania as both separated and connected by water presents a model of the spatiality of va. When this is transferred to relationships in Pasifika education, attention is directed at the way 
spatially-defined classroom interaction is understood. Some non-Pacific understandings see no relationship and no obligation in shared educational spaces beyond teaching/learning, unless these are built or developed. In this understanding there is no relational self (Giddens, 1991). By contrast, Pasifika voice-based taxonomies of preferred teacher characteristics indicate the value of relationality and obligation as consistent and thus deep-rooted. This suggests the prevalence of a relational self where the student and teacher are integrally connected yet separate. Seen through a va lens, schools and classrooms are inevitably sites of social, physical, and spiritual relationships. Activities that Pasifika students understand as positive may serve to intensify relationality. By contrast, inaction or activities which are negatively understood can trample relationality. There is no neutral ground, and no non-relational space.

An understanding of va brings an obligation to nurture relationships (Airini et al., 2010). This can be described through the Samoan reference of teu le va (Airini et al., 2010; Anae, 2010b, 2016) or through the similar Tongan reference tauhi va (Devine, Teisina, \& Pau'uvale, 2012; Ka'ili, 2005). The expectation that one will care for the relational space between people and entities is placed on all involved despite (and because of) the hierarchies inherent in encounters such as education. Teu le va has been explained as caring for va since it involves "balance, symmetry, beauty" (Mila-Schaaf \& Hudson, 2009, p. 117). To care for va is of ethical importance; the ideal is positive connection and minimal conflict "out of concern for the relationship and a desire for harmony and symmetry within the engagement" (p. 117). A developing understanding of va suggests ways of caring for relationships in Pasifika education but does not advocate for any specific behaviour. By nature, va is contextual. As a processual lens, teu le va offers a way of approaching success in Pasifika education, the goal of the present study.

\section{The Brotherhood and Pasifika Success as Pasifika}

In common with others (Alkema, 2014; Luafutu-Simpson et al., 2015), this study provides a wide picture of forms of Pasifika success as Pasifika in education. The specific focus placed on peer relationships is because participants frequently referenced the school's Pasifika brotherhood as a site of success. Two related areas of success are described here: acceptance and resilience. Intersection between forms of success complicates the picture. Data here are drawn from small-scale interviews unless otherwise indicated as from talanoa $(T)$. The dialogue in these sessions was conducted between the students and myself with a main aim of intensifying participant/researcher and student/teacher relationality to prepare for later encounters. Because of the scale of the sample and the singlesite setting, some details have been redacted and/or conflated for reasons of anonymity. 
Acceptance. During interviews and group talanoa, many junior Pasifika students described peer networks based on an ethic of care in which senior students always have my back. This reoccurring phrase, also reported elsewhere (Samu, 2015), was contextualised in various hypothetical situations such as problematic homework, sadness, being bullied, and family matters. Since much data were collected early in the year, no student claimed to have needed such specific help. However, certainty and unquestioned expectation characterised these descriptions of brotherhood support. This suggests that the brotherhood as imagined and/or experienced by these students is not structured around what students need but is characterised by obligation, unquestionably and always present. When asked, "Do you guys think you are having success?" one student replied, "Oh, ha...so far, yes, it's good cos I know A...and they introduced me to all of his friends...they always have my back which is good." Another commented, "They accept me which is pretty cool." Through this relational activity, the brotherhood provides students with success as acceptance. As one boy said, because of the brotherhood, "P.I. boys aren't really alone."

Several students described the speed and totality with which success as acceptance was experienced. Although any new student is likely to be uncomfortable on entry to a new school, Pasifika peer relations can mediate this. As one student put it in his first interview, "I was scared when I first came in but the brotherhood was here." Another explained, "The brotherhood that was here was nice. Everyone just came to you straight away and said 'Hi' and stuff, like they wanted to know you. Straight away, yeah." This immediacy suggests a strong imperative felt by seniors to be positively involved with newcomers, understandable through the obligations inherent in va. Consequently, brotherhood relational proximity can colour the early experience of school for Pasifika students: "It's better than what I thought it was going to be...cos of how close everyone is to each other." This suggests that when enacted, teu le va promotes success as acceptance for junior students through belonging to the brotherhood.

Some students explicitly compared their perceptions of the Pasifika brotherhood with their ideas about the worlds of Palagi peers. Comparisons associated relatedness with the former and individuality with the latter. For instance,

You know how white boys don't include other people but where we do... Like if someone is not doing well with their homework, we always help them. Most people would say, "No you do it yourself," but us P.I. boys we always do it, we always help them.

In this way, the centrality of care and close relationality are distinctively positive aspects of the profile of the brotherhood. A further example elaborates Pasifika students' views of themselves: "[l]f we are real hurt, emotionally they [the brothers] are there to help you.... [White boys] can do that but they just don't do it as good. As like the brown guys... maybe brown people have stronger connection." This suggests that while non-Pasifika students may be able to offer empathy, the bond between Pasifika students seems more powerful and support more readily available. That this power comes from a shared relational language is supported 
by the comment that "if you talk to them [other Pasifika students] it's like how you talk to your brother.... And like, as you talk to them, you talk about similar stuff, and all the communication with each other is like, really well [good]." A senior student reinforced the idea of variation in relational language while facilitating a talanoa for his juniors: "I can joke around and mock around with P.I.s and then Palagis you can talk about different things like sort of talk to them differently $(T)$." Although the student claimed to have Palagi friends, his comment suggests an enduring sense of relational difference.

To summarise, these responses suggest that success as acceptance is a significant form of Pasifika success as Pasifika situated within the brotherhood of the school. Pasifika students see actions that indicate acceptance and that can be understood as expressions of teu le va as distinctive.

Resilience. Associated with acceptance, resilience is a form of Pasifika success that is sited in the brotherhood amongst other spaces. Resilience is the ability to cope with adversity, is alterable (Waxman, Gray, \& Padron, 2003), and is subject to relational support (McMillan \& Reed, 1994). In literature it is generally located in families and teachers. In Pasifika education, the collective strength of the brotherhood offers additional opportunities for the support of resilience. For example, one student explained about his Pasifika peers as such:

...[they] are your brothers, they are basically like your best friends, so that even when you are being successful for a bit, and you just drop completely, they will still be there to like pick you up, support you.

This goes beyond "having my back" because it refers to supporting schoolfocussed success. Another comment which links the brotherhood and resilience is "It's like you know you have got support... when you are down you have always got someone there. You know, that's what a brother does." This explicitly links the role of brothers to resilience. Having someone close provides an opportunity to resist being "down" and to move on.

That success as acceptance and classroom success can be linked in the school is perhaps especially important where Pasifika students are in a minority (Rimoni, 2016). For example, the only Pasifika boy in a class referred to the brotherhood relationship as being "a really strong bond amongst each other so that even if the whole people aren't there, it still feels like they are all there. Like you are walking alone but you feel like all the brothers are like behind you." Here, resilience is supported by the brotherhood in absentia. This suggests that a wellconfigured brotherhood va can support a student in less than ideal contexts through a deep sense of connection. That is, resilience in one space in a school can be resourced by positive relationality in another.

Students in this study acknowledged Poly Club as a forum for brotherhood relationality where "everyone is P.I." Resilience and identity are linked such that Pasifika identity can promote resilience. Identity can be supported through connections maintained in Poly Club: 
Yeah, not many of the P.I. boys are together in classes, so [Poly Club] is sort of time to catch up with the culture. With heaps of Palagis, you can't lose your culture but it seems like you sort of forget about it but this is like a time to remember it.

Poly Club and similar Pasifika spaces within the school, such as Pasifika camp, can be a place where "we don't lose a sense of who we are and where we came from because the brothers will help us." These spaces are opportunities for the brotherhood to strengthen because such opportunities "help all the students connect with other students and vice versa to get an idea of, like, that they are all brothers...that they are all in it together." Brotherhood relationality can be an important resource for Pasifika students through mutual connection and care, and while it is likely to develop regardless of school action, a positive view of brotherhood relationality suggests that schools have an opportunity to support its development, encouraging the acceptance and resilience that it can bring by sponsoring a variety of spaces for interaction.

Conflicting forms of success. Success is defined by identity and values. In complex intercultural areas such as Pasifika education, it is unsurprising that at times there is conflict between forms of success. This has been observed elsewhere and theorised in terms of gender roles of Pacific origin (FairbairnDunlop, 2010a). Comments from students within this study suggest that such conflicts can involve differing priorities, stemming in part from a variety of constructions of what being Pasifika means, and sometimes including a sense of belittlement.

Success as acceptance and success as the pursuit of ambition or selfextension can come into conflict where being Pasifika is not seen as a strength. Some students claimed early in the research that as "one pack...we can do anything we have all wished for." This ideal paints the brotherhood as providing mutual support for limitless ambition. Another claimed, "I don't want to be titled as a lower grade person cos I know I can get good grades," revealing a sense that he might be seen as someone who might lack ability, but countering this with ambition. Later, other students cast light on the way ambition can be viewed within the group. For instance one said, "Some want to be builders, pilots, but then the negativesyou say that in front of all your boys and 'Pilot, you can't be a pilot."' This suggests that conceptual categories of Pasifika, presumably largely sourced from outside of education, operate to limit the kinds of support students may afford each other. In this case, the student's ambition cannot be supported because it is deliberately made invisible. The ideas of Pasifika as "not smart or as known as the brown tail of New Zealand" suggest potential origins for restriction on the expression of ambition.

Several incidents observed during the research year illustrated similar conflicts, the most clear-cut of which took place on a Pasifika induction day. Here, an academically successful senior Pasifika student was given the opportunity to take some juniors to the school library. This was declined with the comment, "These are P.I. boys; they won't want to be reading. They won't want to be in the library." Another comment, again made by a senior with a positive academic record 
as an explanation for not attending a study session, illustrates the same kind of contradiction: "We are rugby players, Miss." This thinking constructs limitations within being Pasifika which contradict the speakers' own academic pathways. As doublethink, this suggests a complex relationship between two Pasifika realitiesone that is experienced as positive and possible, and one that seems to be a limiting ideology. In these circumstances, choice is constructed between forms of success. Actions to teu le va with a group that accepts an identity that excludes being a pilot, reading in a library, or being seen to study, may not sit well with caring for the relational space with individuals who wish to embrace these possibilities. Although such conflicts may be resolved by strategies such as erasure, avoiding the construction of choice between forms of success is a more positive solution, well-served where being Pasifika is regarded as a strength.

Resilience may undercut through the connections inherent in a brotherhood as a result of conflict. The power of brotherhood members to create emotional unpleasantness when the va is sullied matches their potential for providing support. A put-down from a brotherhood member was described as "kind of like being left out. Like if your family went and left you behind, without a reason." This description conveys a sense of unanswered obligation in the expectation that where separation is unavoidable, a reason should be given. This is a failure to teu le va by not considering the needs of another. This can occur in gendered situations. When describing the actions of a brother in a context where girls were present, the following heated exchange occurred:

Your friend would like dog you just to act cool in front of her...

But that's not being a true brother...

Perhaps the significance of this is that the potential support of being a brother is matched by the potential not to be "true" when a conflict occurs. In this case, the sense of having been let down by a betrayal of what Rimoni (2016) calls a "code of responsibility" is clear (p.126).

Contests between different forms of success can take place in classrooms. Inevitably, despite ambition, not every Pasifika student is totally focused on classroom activity. Instead, "some of the boys are like attention seekers." Sitting in class with members of the brotherhood can be helpful but, according to students, "at other times it's quite distracting." One student explained: "Some guys show off to fit in. It's not what they want to be, it's what the boys want them to be, it's like looking in the mirror, but it's like looking at the wrong person." This perceptive comment suggests that classroom activities can host a conflict between the goal of classroom participation and success as acceptance in the brotherhood. What one wishes to be can conflict with what the boys seem to wish. This is reinforced by considering a comment which describes one Pasifika student's perception of the behaviour of others: "They act different to how they really are, their personalities outside and in class." The explanation offered was that "some of the boys are just trying to show off" to those who did not know them. Reinforcing a sense of brotherhood membership can affect the way a student is positioned with respect to classroom participation. The expression "looking in a mirror" indicates 
the relational aspect of this behaviour-it is done for another, and shaped to their expectations. "Showing off" is always to another. This situation illustrates that, within the brotherhood, smaller peer groups can undermine the goals of some while, in response, others can cast a critical eye over their peers. Thus, although the brotherhood has solidarity, this can be contextual and strained at times, such as in the face of conflicts between forms of success.

Pasifika students can behave in agentic ways when faced with such conflicts. Some claim to take control by attempting to sit with students of the same academic focus as themselves. A spatial way of mediating conflict explained by a senior student is to remain seated with the "boys," but to mentally occupy a different space. While this fulfils an obligation of brotherhood solidarity at the physical level, this student's claim of "moving my mind" to the front of the roomto the space occupied by the teacher-perhaps fulfils an obligation to an academic goal, impossible to achieve without a high level of classroom engagement. This highly developed strategy may take time to formulate; it was not present in the accounts of junior students who remained frustrated at times with some of their Pasifika peers. However, it does indicate the multi-level appreciation some students have of their obligations to various relational spaces and their concern to fulfil these without generating conflict.

\section{Implications}

In this study, no student claimed to come to school to fail; many had opted to attend despite obstacles including travel and its associated costs, separation from primary school colleagues, and the inevitability of minority status. Seen through a va lens, Pasifika peer-relationality is a potent force which, if cared for, has the potential to offer acceptance and resource resilience, and support ambition so that goals are achieved. This ideal, however, is not always evident in the accounts of brotherhood members. Questions are therefore raised regarding the processes involved in the muting of the potential of the brotherhood. This includes those circumstances that turn being Pasifika from a strength into a weakness.

One potential explanation can be found by considering how the fabric of education comes to mirror restrictive views of Pasifika present in wider society. This approach suggests links between seemingly distant phenomena such as the way minoritised groups including Pasifika are negatively presented in the media in Aotearoa New Zealand (Loto et al., 2006) and normative, restrictive categories of being Pasifika visible in the practice of education. That such links can exist has been shown by Hynds and Sheehan (2010) and, since schools are an integrated part of society, it would be surprising if this were not the case. Examples of the way restrictive views of Pasifika potential can exist in the fabric of education include the pathways some schools use for Pasifika students, which lead to a dearth of academic challenge (Wilson et al., 2016); the exercise of programme choice in ways that reinforce historical inequity (Madjar, McKinley, Jensen, \& Van Der Merwe, 2009); the concentration of Pasifika students in some areas of schools 
at the expense of others; and the focus on sporting, performance, and leadership success for Pasifika students that draws attention away from a lack of academic success which would be unacceptable for other groups. One could argue that a concentration on NCEA Level 2 in the PEP at the expense of Level 3 and University Entrance has similarly restrictive connotations.

Pursuing Pasifika success as Pasifika requires institutions to acknowledge the potential of groups such as the brotherhood to support success as acceptance. This can then be a resource for resilience. In ways which may differ from some other ethnicities and/or groups that are not minoritised, schools might examine how they interact both with individual students and with the collective. This means understanding that male Pasifika students will form a brotherhood despite a lack of strategy from a school and that, where this happens, the school's opportunity to teu le va with the group has been missed. It also means understanding that, although providing space for a brotherhood in an area such as "culture" can be positive, such selective provision can reinforce externally sourced ideas of Pasifika absence from areas such as academia. Pasifika success as Pasifika would be supported by schools more fully appreciating that choice for their Pasifika students includes individual and/or family ideas of success, but that it can also be a matter of group-defined success. How a group is treated can contribute to its identity, and how a group sees itself can contribute to what success can mean. If education is about the fulfilment of potential, clearing space for success by actively caring for relational matters in ways which make being Pasifika a strength, rather than a restriction, is both an obligation and a logical step.

\section{Concluding Comments}

This article has argued for the value of previous approaches to Pasifika education to construct taxonomies of teacher characteristics that can guide classroom practice and expose the evidence of inequity in the education system through the development of Pasifika data. However, undisturbed concepts of relationships or relationality are problematic, and the narrowness of success implied targeting is an issue.

This article argues for the value of a strengths-based approach, which seeks to understand Pasifika voice through concepts of Pacific origin. Consequently, the construction of conflicts between different kinds of success valued by Pasifika students can be minimised. To teu le va in this context is to recognise, critique, and reshape practice; reduce restriction on Pasifika students; and increase understanding between Pasifika students and their teachers. Seeking the wisdom of va to understand Pasifika education may make space for Pasifika students to pursue Pasifika success as Pasifika, and even transform the context so that Pasifika success becomes success (Nakhid, personal communication, April 21, 2017). This Pacific-based view sits well with the thinking of others (e.g., Valenzuela, 2005) who draw attention to the cultural aspects of education in migration and the way these intersect with power. A concerted effort 
is required to bring new understandings to Pasifika education such that Palagi teachers become learners, administrators become visionaries, and existing practice becomes open to critical questioning from relevant frameworks. Turning to Pacific wisdom for guidance under such circumstances makes a lot of sense. It is an act of "walking backwards into the future while facing the past" (Refiti, 2015, p. 49).

\section{Acknowledgements}

This article is a re-worked, significantly developed, and expanded version of a paper given at the Institute for Interdisciplinary Inquiry Conference, Nadi, Fiji, April 2016. Thanks go to delegates for their advice and assistance. Thanks also to past and present members of Te Kura Māori in the School of Education and Va'aomanū Pasifika at Victoria University for critique and support. Finally, all participants are acknowledged: students, parents, teachers, administrators, and advisors. May we together make a positive difference.

\section{Note}

1. Aotearoa is a Te Reo Māori equivalent for New Zealand. Increasingly the terms are used together to denote the bi-cultural status of the society under the Treaty of Waitangi.

\section{References}

Airini, Anae, M., Mila-Schaaf, K., Coxon, E., Mara, D., \& Sanga, K. (2010). Teu le va - Relationships across research and policy in Pasifika Education: A collective approach to knowledge generation and policy development for action towards Pasifika education success. Wellington, New Zealand: Ministry of Education.

Alkema, A. (2014). Success for Pasifika in tertiary education: Highlights from Ako Aotearoa supported research. Retrieved from https://akoaotearoa.ac.nz/ successforpasifika

Alton-Lee, A. (2003). Quality teaching for diverse students in schooling: Best evidence synthesis. Retrieved from https://www.educationcounts.govt.nz/ publications/series/2515/5959

Anae, M. (2005/2015). Samoans. Te Ara - the Encyclopedia of New Zealand. Retrieved from http://www.TeAra.govt.nz/en/samoans 
Anae, M. (2010a). Research for better Pacific schooling in New Zealand: Teu le va-a Samoan perspective. Mai Review, 1. Retrieved from http://www.review.mai.ac.nz/index.php/MR/article/viewFile/298/395

Anae, M. (2010b). Teu le va: Toward a native anthropology. Pacific Studies, 33(2), 222-240.

Anae, M. (2016). Teu le va: Samoan relational ethics. Knowledge Cultures, 4(3), 117-130.

Boereboom, J. (2016). NCEA pass rate targets - a wolf in sheep's clothing? Retrieved from http://educationcentral.co.nz/ncea-pass-rate-targets-a-wolfin-sheeps-clothing/

Chu, C., Glasgow, A., Rimoni, F., Hodis, M., \& Meyer, L. H. (2013). An analysis of recent Pasifika education research literature to inform and improve outcomes for Pasifika learners. Wellington, New Zealand: Ministry of Education.

Crocombe, R. G. (1976). The Pacific way: An emerging identity. Suva, Fiji: Lotu Pasifika.

Devine, N., Teisina, J. P., \& Pau'uvale, L. (2012). Tauhi vā, Spinoza, and Deleuze in education. Pacific-Asian Education, 24(2), 57-68.

Education Review Office. (2012). Improving education outcomes for Pacific learners. Wellington, New Zealand: Education Review Office.

Education Review Office. (n.d.). Priority learners. Retrieved from http://www.ero.govt.nz/Review-Process/Frameworks-and-EvaluationIndicators-for-ERO-Reviews/He-Pou-Tataki-How-ERO-reviews-earlychildhood-services/PART-2-Outcomes-for-children-in-early-childhoodeducation/Priority-learners

Evans, B. F. (2011). Teaching practices that support high achievement in the education of Pacific boys. (M.Ed), Unitec Institute of Technology, Auckland, New Zealand.

Fa'avae, D., Jones, A., \& Manu'atu, L. (2016). Talanoa 'i 'ae talanoa-talking about talanoa: Some dilemmas of a novice researcher. AlterNative: An International Journal of Indigenous Peoples, 12(2), 138-150.

Fairbairn-Dunlop, P. (2010a). 'He's won, but he's lost it': Applying a Samoa gender lens to education outcomes. AlterNative: An International Journal of Indigenous Peoples, 6(2), 143-154.

Fairbairn-Dunlop, P. (2010b). Pacific youth connecting through 'Poly'. In C. Ward, J. Liu, P. Fairbairn-Dunlop, \& A. Henderson (Eds.), Youth voices, youth choices: Identity, integration, and social cohesion in culturally diverse Aotearoa/New Zealand (pp. 20-29). Wellington, New Zealand: Foundation for Research, Science and Technology. Retrieved from www.victoria.ac.nz/ $\mathrm{cacr} /$ research/youth-family/youth-voices,-youth-choices/Youth-VoicesYouth-Choices-report.pdf 
Farrelly, F., \& Nabobo-Baba, U. (2014). Talanoa as empathic research. Paper presented at the International Development Conference 2012, Auckland, New Zealand.

Giddens, A. (1991). Modernity and self-identity: Self and society in the late modern age. Stanford, CA: Stanford University Press.

Gorinski, R., \& Fraser, C. (2006). Literature review on the effective engagement of Pasifika parents \& communities in education. Wellington, New Zealand: Ministry of Education.

Hau'ofa, E. (1994). Our sea of islands. The Contemporary Pacific, 6(1), 148-161.

Hawk, K., \& Hill, J. (2000). Making a difference in classrooms: Effective teacher practice in low-decile, multi-cultural schools. Wellington, New Zealand: Ministry of Education Research Division.

Helu-Thaman, K. (1988). Ako and Faiako: Educational concepts, cultural values and teachers' role perception in Tonga. (Unpublished PhD Dissertation), University of the South Pacific, Suva, Fiji.

Helu-Thaman, K. (2010). Teacher capacities for working towards peace and sustainable development. International Journal of Sustainability in Higher Education, 11(4), 353-364.

Hoem, I. (1993). Space and morality in Tokelau. Pragmatics, 3(2), 137-153.

Hynds, A., \& Sheehan, M. (2010). Iwi versus Kiwi: Racism, race relationships and the experience of controversial political debates within a context of culturally responsive school reform. New Zealand Annual Review of Education, 20, 102-121.

Ka'ili, T. O. (2005). Tauhi va: Nurturing Tongan sociospatial ties in Maui and beyond. The Contemporary Pacific, 17(1), 83-114.

Latu, S., \& Young, A. (2004). Teaching ICT to Pacific Island background students. Paper presented at the Sixth Australasian Conference on Computing Education, Dunedin, New Zealand. Retrieved from http://crpit.com/ confpapers/CRPITV30Latu.pdf

Latu, V. F. (2004). There is more to learning mathematics than mathematics: Attributional beliefs and motivation of Maori and Pacific Island students. Paper presented at the Mathematics Education for the Third Millennium: Towards 2010 conference, Townsville, Australia. Retrieved from https://www.merga.net.au/documents/RP402004.pdf

Lilomaiava-Doktor, S. (2009). Beyond "migration": Samoan population movement (malaga) and the geography of social space (vā). The Contemporary Pacific, 21(1), 1-32.

Loto, R., Hodgetts, D., Chamberlain, K., Nikora, L. W., Karapu, R., \& Barnett, A. (2006). Pasifika in the news - The portrayal of Pacific peoples in the New Zealand press. Journal of Community \& Applied Social Psychology, 16(2), 100-118. 
Luafutu-Simpson, P., Moltchanova, E., O'Halloran, D., Petelo, L., Schischka, J., \& Uta'i, S. (2015). Change strategies to enhance Pasifika student success at Canterbury tertiary institutions. Wellington, New Zealand: Ako Aotearoa.

Madjar, I., McKinley, E., Jensen, S., \& Van Der Merwe, A. (2009). Towards University: Navigating NCEA Course Choices in Low-Mid Decile Schools. Starpath Project. Retrieved from http://www.education.auckland.ac.nz/uoa/ home/about/research/starpath-home/starpath-research/towards-university

McMillan, A. (2012). Exploring the role of the Rock and Water programme in the improvement of Māori and Pasifika boys' engagement with school. (MEd), Victoria University of Wellington, Wellington, New Zealand.

McMillan, J. H., \& Reed, D. F. (1994). At-risk students and resiliency: Factors contributing to academic success. The Clearing House, 67(3), 137-140.

Mila-Schaaf, K. (2006). Va-centred social work: Possibilities for a Pacific approach to social work practice. Social Work Review, 18(1), 8-13.

Mila-Schaaf, K., \& Hudson, M. (2009). Negotiating space for indigenous theorising in Pacific mental health and addictions. Auckland, New Zealand: Le Va.

Milne, A., \& Students of Kia Aroha College. (2015). Speaking out as "Maori": Maori secondary students investigate our system's vision for Maori learners. Paper presented at the Te tora titiro tawhiti: Emancipation through education. NZARE Conference 2015, Whakatane, New Zealand.

Ministry of Education. (2013). Pasifika education plan. Retrieved from http://www.education.govt.nz/ministry-of-education/overall-strategies-andpolicies/pasifika-education-plan-2013-2017/

Ministry of Education. (2015). Education Counts: Progress against Pasifika Education Plan targets. Retrieved from https://www.educationcounts. govt.nz/statistics/pasifikaeducation/progress_against_pasifika_education_ plan_targets

Moll, L. C. (2015). Tapping into the "hidden" home and community resources of students. Kappa Delta Pi Record, 51(3), 114-117.

Nakhid, C. (2003). "Intercultural" perceptions, academic achievement, and the identifying process of Pacific Islands students in New Zealand schools. The Journal of Negro Education, 72(3), 297-317. doi:10.2307/3211249

New Zealand Qualifications Authority. (2013). Annual Report on NCEA and New Zealand Scholarship Data and Statistics (2012). Retrieved from http://www.nzqa.govt.nz/studying-in-new-zealand/secondary-school-andncea/find-information-about-a-school/secondary-school-statistics/

New Zealand Qualifications Authority. (2014). Annual report on NCEA and New Zealand Scholarship data and statistics (2013). Retrieved from http://www.nzqa.govt.nz/assets/About-us/Publications/stats-reports/nceaannualreport-2013.pdf 
New Zealand Qualifications Authority. (2015). Annual report on NCEA and New Zealand Scholarship data and statistics (2014). Retrieved from http://www.nzqa.govt.nz/assets/About-us/Publications/stats-reports/nceaannualreport-2014.pdf

Office of the Auditor-General. (2012). Roles of public entities in education for Māori. Retrieved from http://www.oag.govt.nz/2012/education-for-maori/ part2.htm

Orange, C. (2012). Treaty of Waitangi. Te Ara - the Encyclopedia of New Zealand. Retrieved from http://www.TeAra.govt.nz/en/treaty-of-waitangi

Poltorak, M. (2007). Nemesis, speaking, and tauhi vaha'a: Interdisciplinarity and the truth of "Mental Illness" in Vava'u, Tonga. The Contemporary Pacific, 19(1), 1-35.

Redmond, A. (2017). Maori and Pasifika NCEA pass rates improved, but disparity persists at university. The Dominion Post. Retrieved from http://www.stuff.co.nz/national/education/91572347/maori-and-pasifikancea-pass-rates-improved-but-disparity-persists-at-university

Refiti, A. (2015). Mavae and Tofiga: Spatial exposition of the Samoan cosmogony and architecture. (PhD), Auckland University of Technology, Auckland, New Zealand.

Reynolds, M. (2016). Relating to va. AlterNative: An International Journal of Indigenous Peoples, 12(2), 190-202. doi:10.20507/AlterNative.2016.12.2.7

Reynolds, M. (2017a). Together as brothers: A catalytic examination of Pasifika success as Pasifika to teu le va in boys' secondary education in Aotearoa New Zealand. (PhD), Victoria University of Wellington, Wellington, New Zealand. Retrieved from http://researcharchive.vuw.ac.nz/handle/ $10063 / 6487$

Reynolds, M. (2017b). Video and va: Caring for relationality in Pasifika education. Set - Research Information for Teachers. Retrieved from http://www.nzcer.org.nz/nzcerpress/set/articles/video-and-v-caringrelationality-pasifika-education

Rimoni, F. (2016). Tama Samoa stories: Experiences and perceptions of identity, belonging and future aspirations at secondary school. (Unpublished PhD Dissertation), Victoria University of Wellington, Wellington, New Zealand.

Samu, N. P. (2015). "It's not about that as long as I'm playing with the boys": The sporting and academic achievement of Pasifika males in their senior years of secondary schooling. (Master of Professional Studies in Education), University of Auckland, Auckland.

Samu, T. (2006). The 'Pasifika Umbrella' and quality teaching: Understanding and responding to the diverse realities within. Waikato Journal of Education, 12, 35-50. 
Siope, A. (2011). The schooling experiences of Pasifika students. Set - Research Information for Teachers, 3, 10-16.

Spiller, L. T. (2013). Teachers' misunderstandings that affect the learning of their Pasifika students. (M Ed.), Victoria University of Wellington, Wellington, New Zealand.

Spoonley, P. (1988). Racism and ethnicity. Oxford, England: Oxford University Press.

Statistics New Zealand. (2014). 2013 census ethnic group profiles. Retrieved from http://www.stats.govt.nz/Census/2013-census/profile-and-summaryreports/ethnic-profiles.aspx

Suaalii-Sauni, T., \& Fulu-Aiolupotea, S. M. (2014). Decolonising Pacific research, building Pacific research communities and developing Pacific research tools: The case of the talanoa and the faafaletui in Samoa. Asia Pacific Viewpoint, 55(3), 331-344. doi:10.1111/apv.12061

Tanielu, R., \& Johnson, A. (2013). More than churches, rugby \& festivals: A report on the state of Pasifika people in New Zealand. Retrieved from www.salvationarmy.org.nz/socialpolicy

Toumu'a, R. (2014). Pasifika success as Pasifika: Pasifika conceptualisations of literacy for success as Pasifika in Aotearoa New Zealand. Wellington, New Zealand: Adult and Community Education in Aotearoa (ACE).

Treasury. (2012). Budget 2012 information release. Retrieved from http://www.treasury.govt.nz/publications/informationreleases/budget/2012/ pdfs/b12-2339097.pdf

Tuagalu, I. (2008). Heuristics of the va. AlterNative: An International Journal of Indigenous Scholarship, 4(1), 107-126.

Tupuola, A. M. (2004). Pasifika edgewalkers: Complicating the achieved identity status in youth research. Journal of Intercultural Studies, 25(1), 87-100.

Turner, R., Irving, E., Li, M., \& Yuan, J. (2010). Availability of NCEA standards: Impact on success rate. Auckland, New Zealand: Starpath Project, The University of Auckland.

Valenzuela, A. (2005). Subtractive schooling, caring relations, and social capital in the schooling of US-Mexican youth. In L. Weis \& M. Fine (Eds.), Beyond silenced voices: Class, race, and gender in United States schools (pp. 8394). Albany, NY: SUNY Press.

Visser, H., Unasa, L., Kennedy, S., \& Airini. (2007). Is your research making a difference to Pasifika Education? Paper presented at the Education in the Pacific- NZARE Annual Conference Christchurch.

Waxman, H. C., Gray, J. P., \& Padron, Y. N. (2003). Review of research on educational resilience. Research report. Retrieved from http://escholarship.org/uc/item/7x695885\#page-1 
Wendt, A. (1999). Afterword: Tatauing the post-colonial body. In V. Hereniko \& R. Wilson (Eds.), Inside out: Literature, cultural politics, and identity in the new Pacific (pp. 399-412). Lanham, MD: Rowman \& Littlefield.

Wilson, A., Madjar, I., \& McNaughton, S. (2016). Opportunity to learn about disciplinary literacy in senior secondary English classrooms in New Zealand. The Curriculum Journal, 27(2), 204-228.

\section{Author Contact}

Martyn Reynolds: msdfreynolds@gmail.com

Victoria University of Wellington, PO Box 600, Wellington 6140, New Zealand 